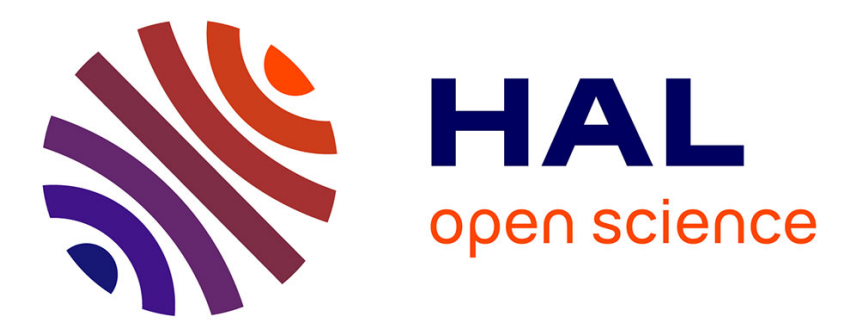

\title{
Regulation of toxin synthesis in Clostridium botulinum and Clostridium tetani
}

Chloé Connan, Cécile Denève, Christelle Mazuet, Michel R. Popoff

\section{To cite this version:}

Chloé Connan, Cécile Denève, Christelle Mazuet, Michel R. Popoff. Regulation of toxin synthesis in Clostridium botulinum and Clostridium tetani. Toxicon, 2013, 75 (3), pp.90 - 100. 10.1016/j.toxicon.2013.06.001 . pasteur-01792396

\section{HAL Id: pasteur-01792396}

https://hal-pasteur.archives-ouvertes.fr/pasteur-01792396

Submitted on 1 Aug 2018

HAL is a multi-disciplinary open access archive for the deposit and dissemination of scientific research documents, whether they are published or not. The documents may come from teaching and research institutions in France or abroad, or from public or private research centers.
L'archive ouverte pluridisciplinaire HAL, est destinée au dépôt et à la diffusion de documents scientifiques de niveau recherche, publiés ou non, émanant des établissements d'enseignement et de recherche français ou étrangers, des laboratoires publics ou privés.

\section{(1)(1) $\$(0)$}

Distributed under a Creative Commons Attribution - NonCommercial - ShareAlikel 4.0 


\section{REGULATION OF TOXIN SYNTHESIS IN CLOSTRIDIUM BOTULINUM AND CLOSTRIDIUM TETANI}

Chloé CONNAN, Cécile DENÈVE, Christelle MAZUET, Michel R. POPOFF*

Institut Pasteur, Unité des Bactéries Anaérobies et Toxines, Paris, France

Key words: Clostridium botulinum, Clsotridfium tetani, botulinum neurotoxin, tetanus toxin, regulation

Corresponding author

Institut Pasteur, Unité des Bactéries Anaérobies et Toxines, 25 rue du Dr Roux, 75724 Paris cedex 15, France

mpopoff@pasteur.fr 


\section{ABSTRACT}

Botulinum and tetanus neurotoxins are structurally and functionally related proteins that are potent inhibitors of neuroexocytosis. Botulinum neurotoxin (BoNT) associates with non-toxic proteins (ANTPs) to form complexes of various sizes, whereas tetanus toxin (TeNT) does not form any complex. The BoNT and ANTP genes are clustered in a DNA segment called the botulinum locus, which has different genomic localization (chromosome, plasmid, phage) in the various Clostridium botulinum types and subtypes. The botulinum locus genes are organized in two polycistronic operons (nthh-bont and ha/orfX operons) transcribed in opposite orientations. A gene called botR lying between the two operons in $C$. botulinum A encodes an alternative sigma factor which regulates positively the synthesis of BoNT and ANTPs at the late exponential growth phase and beginning of the stationary phase. In C. tetani, the gene located immediately upstream of tent encodes a positive regulatory protein, TetR, which is related to BotR. C. botulinum and C. tetani genomes contain several two-component systems and predicted regulatory orphan genes. In C. botulinum type A, three two-component systems have been found to positively regulate the synthesis of BoNT and ANTPs independently of BotR/A. The synthesis of neurotoxin in Clostridia seems to be under the control of complex network of regulation.

\section{INTRODUCTION}

Among the large number of Clostridium species, which are bacteria from the environment, some of them produce potent neurotoxins and are responsible for neurological disorders in human and animals. Botulinum neurotoxins (BoNTs) inhibit the release of acetylcholine at peripheral cholinergic nerve terminals causing the flaccid paralysis of botulism, whereas tetanus neurotoxin (TeNT) blocks neurotransmitter release at synapses at the central nervous system causing the spastic paralysis of tetanus. In the last decades, numerous works have been performed to elucidate the structure and mechanism of action of the clostridial neurotoxins as well as their genetic organization and regulation.

\section{2 . CLOSTRIDIA PRODUCING NEUROTOXINS}

Clostridia capable of producing BoNT display heterogeneous bacteriological characters and are divided into several species and groups. The taxonomic position of the $C$. botulinum species was originally based on only one phenotype, the production of a BoNT, and non-toxic variant strains, although genetically related to C. botulinum, were assigned to different species such as Clostridium sporogenes and Clostridium subterminale. It appeared 
soon that BoNTs are divided into seven different neurotoxin types, which are immunologically distinct and are termed with letters from A to G. They exhibit 34 to $64 \%$ identity at the amino acid sequence level. More recently, sequence analysis of a large number of bont genes permits to distinguish subtypes varying from 2.6 to $31.6 \%$ at the amino acid sequence level within each BoNT type (Carter et al., 2009; Chen et al., 2007; Hill et al., 2007; Raphael et al., 2012; Smith et al., 2005). However, all of them cause the typical flaccid paralysis of botulism in experimental animals, similar to that observed in human patients suffering from botulism. Later on, physiological differences between C. botulinum strains were identified, but the production of the different BoNT types does not necessarily correlate with the $C$. botulinum strain phenotypes. The species was divided into 4 physiological groups (Smith, 1975).

- Group I : C. botulinum A, and proteolytic strains of C. botulinum B and F.

- Group II : C. botulinum E, and glucidolytic strains of C. botulinum B and F.

- Group III : C. botulinum C and D.

- Group IV : C. botulinum G (or C. argentinense).

The latter group which also includes non-toxic strains previously identified as $C$. subterminale and C. hastiforme, is metabolically distinct from the other groups and has been assigned to a different species called C. argentinense (Suen et al., 1988). The taxonomic position of $C$. botulinum became more ambiguous since it has been found that BoNTs can be produced by Clostridium strains clearly distinct from already defined C. botulinum, and biochemically and genetically related to different species. Thereby, atypical strains of Clostridium butyricum and Clostridium baratii produce a BoNT related to type E and F, respectively (Hall et al., 1985; McCroskey et al., 1986; McCroskey et al., 1991). In each group of $C$. botulinum or other Clostridium species, the toxigenic strains regardless of toxin types, are closely related according to their phenotypic and genetic properties.

In contrast, tetanus neurotoxin (TeNT) is produced by a uniform group of bacteria belonging to the Clostridium tetani species. The $C$. tetani species contains toxigenc and nontoxigenic strains and is similar culturally and biochemically to $C$. cochlearium and $C$. tetanomorphum, but it can be distinguished from the two latter species by DNA comparison (Nakamura et al., 1979; Wilde et al., 1989). Ten neurotoxigenic and three non-toxigenic $C$. tetani strains studied by Nakamura et al. were homogeneous in DNA/DNA hybridization (8593\% similarity) (Nakamura et al., 1979). Genome sequence is available for only one C. tetani strain (see below). 


\section{3 . NEUROTOXIN GENE ORGANIZATION}

\subsection{The botulinum locus}

The genes encoding the neurotoxins and associated non toxic proteins (ANTPs), which associate with BoNT to form the botulinum complexes, have been cloned and sequenced in representative clostridial strains of each BoNT type. The neurotoxin and ANTP genes are clustered in close vicinity and constitute the botulinum locus. They are organized in two operons. The bont gene is immediately preceded by the gene of the NTNH component. Both genes form an operon located in the 3' part of the botulinum locus, which is well conserved in the different types of BoNT-producing Clostridia. The HA or Orfx genes, which are upstream to the $n t n h$-bont genes, are transcribed in the opposite orientation and form the second operon. The HA operon (ha33, hal7, ha70) is associated with bontB, bontC, bontD, bontG, whereas the OrfX operon $(\operatorname{orf} X 1, \operatorname{orf} X 2$ and $\operatorname{orf} X 3)$ is linked to bontA2, A3, A4, E and $F$ and a gene (p47) encoding a $47 \mathrm{kDa}$ protein lies immediately upstream of the $n t n h$ gene (Dineen et al., 2004; Jacobson et al., 2008). bont/A1 is the only gene which has been found in either HA or Orfx botulinum locus.

A gene, botR, which encodes an alternative sigma factor involved in the regulation of botulinum locus gene expression (Raffestin et al., 2005), is present in different positions in different strains of $C$. botulinum. In C. tetani, a gene (tet $\mathrm{R}$ ) equivalent to bot $\mathrm{R}$ (Marvaud et al., 1998a; Raffestin et al., 2005) is present upstream of the tetanus toxin (tent) gene. No antplike genes have been identified in C. tetani (Brüggemann et al., 2003). It is noteworthy that bot $/ \mathrm{R}$ is not present in botulinum locus containing the bont/E gene, in $C$. botulinum or $C$. butyricum type E.

Usually, one clostridial strain produces only one type of neurotoxin and the botulinum locus is present in a single copy on the genome as suggested by Southern blotting of DNA fragments separated by pulse-field gel electrophoresis (Hutson et al., 1996; Lin and Johnson, 1995). However, some strains synthesize two different BoNTs such as BoNT/A-BoNT/B, BoNT/A-BoNT/F, and BoNT/B-BoNT/F (Henderson et al., 1997; Hutson et al., 1996). The bivalent strains contain two botulinum loci. For example, the $\mathrm{AB}$ strain contains two botulinum loci exhibit OrfX-BoNT/A1 and HA-BoNT/B loci, which are $40 \mathrm{kbp}$ distant on the chromosome. In such strains, the two neurotoxins are usually produced in different proportions. Thus, in $\mathrm{Ba}$ and $\mathrm{Bf}$ strains, BoNT/B is produced ten times more, than BoNT/A and BoNT/F (Henderson et al., 1997; Hutson et al., 1996). Some clostridial strains contain silent neurotoxin genes. Indeed, several C. botulinum A strains isolated from food borne and infant botulism contain a silent bont/B gene and are noted $\mathrm{A}(\mathrm{b})$. The bont/B nucleotide 
sequence is related to that of $C$. botulinum B strains ( $97 \%$ identity), but it has a stop mutation in position 128 and base deletions resulting in reading frameshifts and multiple stop codons (Dineen et al., 2004; Hutson et al., 1996; Jovita et al., 1998). Silent bont/B has also been evidenced in non toxigenic C. subterminale strains (Franciosa et al., 1994; Jovita et al., 1998).

\subsection{Genomic localization of the botulinum locus}

The genes encoding for the different types of BoNT are present on different genetic elements, including phage, plasmid or chromosome depending on the species and strain of Clostridia. In $C$. tetani and $C$. argentinense, the neurotoxin gene is present within a large plasmid (51 and $76 \mathrm{MDa}$ respectively). Plasmids of various sizes and bacteriophages have been found in C. botulinum A, B, E, and F and previous works have shown that toxigenicity was not associated with the presence of these genetic elements (Eklund et al., 1989; Strom et al., 1984; Weickert et al., 1986). Therefore, the genes encoding these neurotoxins were assumed to be located on the chromosome. However, it has been recently found that in some strains such as Loch Maree strain (subtype A3), 657Ba (type Ba and subtype A4), Okra (type B1), and Eklund 17B (type Bnp) the botulinum neurotoxin genes are harbored by large plasmids (47 to $270 \mathrm{~kb}$ ) (Marshall et al., 2007; Smith et al., 2007). Plasmid location of neurotoxin genes seems common in C. botulinum type B strains, mainly in subtype B1, bivalent, and non proteolytic strains (Franciosa et al., 2009). In the bivalent strain Ba657 the two botulinum locus, locus A and locus B, are located on the same plasmid and are separated by approximately $97 \mathrm{kbp}$. Similarly, the neurotoxin genes, bontB and bont/f, from one Bf strain are located on a same plasmid (pBf), which is highly related to pCLJ from 657Ba strain (Hill et al., 2009). Interestingly, none of botulinum plasmid show synteny to $C$. tetani plasmid pE88, which contains the tent gene (Hill et al., 2009). In C. botulinum type $\mathrm{E}$ and neurotoxigenic $C$. butyricum strains, the location of the BoNT/E encoding gene is located on the chromosme. In C. botulinum $\mathrm{C}$ and $\mathrm{D}$, it has been clearly evidenced that BoNT is encoded by bacteriophages (reviewed in (Poulain et al., 2006)).

The location of botulinum locus within chromosome or plasmid seems to occur not at random but at specific sites. Indeed, in strains from group I or II, whose genome sequencing is available, three specific sites of botulinum locus integration have been identified. OrfX-A2, orfX'-A1, and orfX-F locus are located in the ars operon, which contains 3 to 5 genes involved in arsenic reduction. OrfX'-A1 and orfX-F locus share a similar integration site at the 5 ' end of the ars operon, whereas OrfX-A2 locus is inserted between two copies of ars $C$ gene. HA-A1 and HA-B locus, which contain a recombinant ntnh gene type A and type B 
strains, are found in the oppA/brnQ operon encoding an extracellular solute binding protein and branched chain amino acid transport proteins, respectively. This operon is lacking in nonproteolytic $C$. botulinum type B, C. botulinum type E, and $C$. butyricum type E strains. The third integration site is the rarA gene, which contains the OrfX-E locus in C. botulinum type E and C. butyricum type E strains. rarA encodes a resolvase protein involved in recombination or insertion events of transposons. Interestingly, the botulinum E locus is inserted in the same codon (102) of rarA gene in both $C$. botulinum type E and C. butyricum type E strains, and the inserted botulinum locus contains an additional intact rarA gene (Hill et al., 2009)

Two specific sites of botulinum locus location have been identified on plasmids from group I strains, one contains OrfX-A3, OrfX-A4 from Ba strain, or OrfX-F from Bf strain, and the second harbors the HA-B locus from C. botulinum B1 strain or bivalent $\mathrm{Ba} 4$ or $\mathrm{Bf}$ strains. The HA-non-proteolytic (np)B locus is located on a plasmid different from those of group I strains. However, the downstream flanking region of the HA-npB locus contains an IS element, a transposon-associated resolvase, and a site specific recombinase (Hill et al., 2009). The localization of the botulinum locus on plasmid or phage in numerous strains, and the presence of insertion sequences in $C$. botulinum genomes, some of them flanking the botulinum locus, as well as transposon associated genes suggest horizontal transfer of the neurotoxin genes between Clostridium strains and subsequent evolution in each strain, notably by recombination events (Hill et al., 2009; Skarin and Segerman, 2011).

\subsection{The tetanus locus}

The complete genome sequence of a toxigenic $C$. tetani strain has been determined (Brüggemann et al., 2003). It consists of a $2799250 \mathrm{bp}$ chromosome containing 2372 putative genes, and of a 74082 bp plasmid (E88) containing 61 genes. C. tetani possesses many genes for peptidases, amino acid and lipid degradation, whereas genes for sugar utilization are lacking. It contains numerous transport-related genes, in particular 35 genes for sodium iondependent systems indicate that $\mathrm{Na}^{+}$gradient is a major driving force in membrane transport. The TeNT encoding gene and seven putative regulatory genes are localized on the plasmid, whereas the tetanolysin (a hemolysin) gene and putative adhesin genes are located on the chromosome. In contrast to $C$. botulinum, the tent gene is preceded by tetR, which is analogous to botR. But, no gene related to $C$. botulinum antp genes, lies in the flanking regions of tent or in another localization in the C. tetani genome. Therefore, TeNT differs from BoNT as it does not form any complex with non-toxic proteins. 
The few mobile elements, whose most of them seem to be non functional because of mutations, and the low $\mathrm{G}+\mathrm{C}$ variation support a high stability of the $C$. tetani genome without recent gene acquisition by horizontal transfer. Only a few genes of the E88 plasmid show similarity with coding sequences from other bacterial species yielding mysterious the origin of this plasmid harboring neurotoxin gene (Brüggemann et al., 2003).

\section{TOXIN GENE REGULATION}

C. botulinum strain Hall contains 28 two-component systems, 8 orphan histidine kinases, 8 orphan response regulators, and 15 sigma factors (Sebaihia et al., 2007). Little is still known about the regulation mechanisms in $C$. botulinum. The most studied regulation systems concern those involved in the control of the neurotoxin synthesis.

\section{1 bont and antp genes are transcribed as two operons}

Transcriptional analysis has been investigated in C. botulinum A and C (Hauser et al., 1995; Henderson et al., 1996). In C. botulinum C, a transcription start site was mapped 113 nucleotides upstream of the ATG of $n t n h / C$, and another one 100 nucleotides upstream of the initial codon of bont $/ \mathrm{C} 1$. Both genes are preceded by a consensus ribosome binding site (GGAGG). The analysis of mRNA by reverse transcriptase PCR (RT-PCR) showed that a mRNA overlaps bont/C1 and $n t n h / \mathrm{C} 1$ genes possibly encoding both genes (Hauser et al., 1995). Similar results were found in C. botulinum A NCTC 2916 (Henderson et al., 1996). Two transcripts have been identified for bont/A gene. The longer $(7.5 \mathrm{~kb})$ encompasses the ntnh-bont/A genes, and the shorter $(4 \mathrm{~kb})$ corresponds to bont/A alone. This indicates that bont/A and bont/C1 are transcribed as a mono or a bicistronic messenger in association with the corresponding ntnh gene. Transcriptional analysis in C. botulinum KyotoF type A2 showed that neurotoxin genes are transcribed only as a tricistronic operon, $p 47-n t n h$-bont/A2, with a transcriptional origin 28 nucleotides upstream of the ATG of $p 47$, and no RNA messenger specific of bont/A2 alone was evidenced (Dineen et al., 2004). Using RT-PCR, it was found that at least one mRNA overlaps the 3 ha genes in C. botulinum C (Hauser et al., 1995). By Northern blots in C. botulinum A NCTC2916, a single $3.2 \mathrm{~kb}$ transcript encompasses ha35, ha17 and ha70 genes (Henderson et al., 1996). A transcriptional start site was mapped 34 nucleotides upstream of the ATG of ha35. Therefore, has seem to form a tricistronic operon. However, the HA35 or HA33 components in C. botulinum A and C respectively, were found to be produced in higher amount than the other HA components (Inoue et al., 1996). This suggests that the relative levels of synthesis of the 3 HA components 
are controlled at the translational level as it was found for other toxin such as cholera toxin (Hirst, 1995). In C. botulinum with a subtype A2 locus organization, the transcriptional analysis also revealed that $\operatorname{orf} X 1, \operatorname{orf} X 2$ and $\operatorname{orf} X 3$ genes are transcribed as a tricistronic operon. A $5.5 \mathrm{~kb}$ transcript encompassing the three genes was detected and a transcriptional start site was mapped 1179 nucleotides upstream of the ATG of orfX1 (Dineen et al., 2004).

The genetic organization in the other $C$. botulinum types shows that bont and antp genes are localized in two clusters which can be considered as polycistronic units in comparison with the findings reported in C. botulinum A and C.

\subsection{BotR and TetR positively regulates neurotoxin gene expression}

It was first reported that in $C$. botulinum $\mathrm{C}$, a gene $($ bot $R / \mathrm{C})$ encodes a $22 \mathrm{kDa}$ protein having the feature of a DNA binding protein: basic pI (10.4) and presence of helix-turn-helix motif (Hauser et al., 1995). This gene is conserved in proteolytic and non proteolytic $C$. botulinum A, B, D, F and G, and in C. tetani (tetR) (Bhandari et al., 1997; East et al., 1996; Henderson et al., 1996; Li et al., 1998). However, it has not yet been detected in C. botulinum E. tet $\mathrm{R}$ is the only gene related to a gene from the botulinum locus which is conserved in $C$. tetani. tet $R$ is localized immediately upstream of the tent gene .

BotRs from the different toxinotypes and TetR have 51 to $97 \%$ identity and are related to other known regulatory proteins such as UviA (25-28\% identity) which regulates the bacteriocin production in $C$. perfringens, MsmR protein (21-26\%) which regulates the sugar transport in Streptococcus mutans, and TcdR (20-24\%) in C. difficile (previously named TxeR) a positive regulator of Toxin A and Toxin B genes ( $t c d A$ and $t c d B)$. Interestingly, $t c d \mathrm{R}$ and $u v i \mathrm{~A}$ have similar localization than that of botR and tet $\mathrm{R}$ since they lie upstream of the locus of $t c d A$ and $t c d B$, as well as bacteriocin gene $(b c n)$, respectively. We have analyzed the function of botR/A by overexpressing this gene in C. botulinum A. botR/A was cloned under the control of its own promoter in a high copy number shuttle vector which was transferred in C. botulinum A by electroporation. Overexpression of botR/A increases the BoNT/A and ANTPs production and of the corresponding mRNA levels. Inversely, partial inhibition of the botR/A expression by antisense mRNA results in a lower production of BoNT/A and ANTPs. It was concluded that BotR/A is a transcriptional activator of bont and antp genes (Marvaud et al., 1998b). Interestingly, overexpression of $b o t R / \mathrm{A}$ and to a lesser extent $b o t R / \mathrm{C}$ in $C$. tetani enhance TeNT synthesis (Marvaud et al., 1998a), thus indicating that BotR and TetR share in vivo a similar mechanism of action. This also indicates that the regulation of the bont and tent genes is conserved in $C$. botulinum and $C$. tetani, and this constitutes a further 
evidence that bont and tent gene locus derive from a common ancestor (Marvaud et al., 1998a).

4.3 BotR and TetR are alternative sigma factors controlling the expression of the neurotoxin and associated protein genes

BotR/A binds to $n t n h$-bont/A and ha35 promoters, the two operon promoters, in a dose dependent manner only when associated with E. coli RNA polymerase core enzyme (Core) (Raffestin et al., 2005). BotR/A-Core interacts specifically with the operon promoters and also with the putative promoters of the other botulinum locus genes (bont/A, botR/A, ha17, ha70). In in vitro transcription, transcripts were observed when BotR/A-Core was incubated only with DNA templates containing $n t n h$-bont/A and ha35 promoters. Thereby, BotR/A is an alternative sigma factor required for specifc expression of the botulinum locus operons.

Footprinting experiments with DNA fragment containing ntnh-bont/A promoter indicate that the conserved -10 (GTTATA) and -35 (TTTACA) promoter sequences, are the motif signatures recognized specifically by the sigma factor BotR/A. Sequences of $-35-10$ regions of ntnh-bont/A promoter are conserved in ha35 promoter of C. botulinum A, also in the corresponding promoters of $C$. botulinum $\mathrm{B}, \mathrm{C}, \mathrm{D}$ and $\mathrm{G}$, as well as in tent promoter in $C$. tetani. The consensus promoter site sequences are ATTTTagGTTTACAAAA for the -35 and ATGTTATATataa for the -10 regions (Popoff and Marvaud, 1999). The -35 box contains the hexa-motif TTTACA which has also been found in the corresponding promoter sequence recognized by TcdR and UviA.

The role of BotR/A is probably not restricted to the control of the botulinum locus genes but has a pleiotropic effect in $C$. botulinum. Indeed, when botR/A is overexpressed in $C$. botulinum A (Marvaud et al., 1998b), 22 genes were overexpressed at least 4 fold and 67 decreased compared to the wild type strain as monitored by a transcriptomic analysis, and when $\operatorname{bot} R / A$ is partially repressed by an antisense RNA system (Marvaud et al., 1998b), 15 genes were overexpressed and 6 decreased (data not shown).

4.4 BotR and TetR belong to a new subgroup of the $\sigma 70$ family of RNA polymerase sigma factors (Group 5)

It has also been demonstrated that UviA is required, as alternative sigma factor, for transcription of UV-inducible bacteriocin gene in C. perfringens (Dupuy et al., 2005). The majority of the sigma factors in eubacteria belong to the $\sigma 70$ family, which can be divided in four structurally and functionally related groups. BotR, TetR, TcdR and UviA have some 
similarities with the extra cytoplasmic function (ECF) group (group 4). Because they differ sufficiently in structure and function, it was suggested that they form a new group (group 5) that is distantly related to the $\sigma 70$ family (Helmann, 2002).

Interchangeability between BotR/A, BotR/C and TetR was first demonstrated in vivo in C. tetani (Marvaud et al., 1998a). Then, the four sigma factors, BotR/A, TetR, TcdR and UviA were found to be functionally interchangeable in vitro and in vivo (Dupuy et al., 2006). The functional conservation of sigma factors of group 5 suggests the idea that the members of group 5 were derived from a common ancestor. A common molecular mechanism is involved in the regulation of synthesis of potent Clostridium toxins (BoNT, TeNT, TcdA, and TcdB) and bacteriocin.

4.5 The expression of botR/A and other botulinum locus genes occurs during the transition from the exponential to the stationary growth phase

Expression of botR/A, bont/A and antps genes in C. botulinum $\mathrm{A}$ strain Hall and NCTC2916 have been monitored by reverse transcription and real-time PCR analysis (Couesnon et al., 2006) . Expression of botR/A is concomitant with that of bont/A and antps. All botulinum locus genes follow the same kinetic of expression in sporulated or non sporulated cultures. However, the relative expression of botR/A in both strains was approximately 100 fold less than those of the other botulinum locus genes. Expression of botulinum locus genes is low during the exponential growth, increases at a maximum level (100 fold increase) at the transition phase between late exponential and stationary growth phase, and then decreases during the stationary phase. After $24 \mathrm{~h}$ incubation, relative gene expression decreases to levels found in the early growth phase. The highest toxin concentration (monitored by mouse lethal activity) is observed at $24 \mathrm{~h}$ ( $12 \mathrm{~h}$ after the maximal gene expression), and is stable for a period of at least 5 days. These results are in agreement with previous reports for C. botulinum A strains A62, Hall and NCTC2916 using analysis of mRNA transcripts by Northern hybridization (Bradshaw et al., 2004). Moreover, in strain NCTC2916, in sporulated or non sporulated conditions, the relative expression of bont/A is approximately twice than that of $n t n h / \mathrm{A}$, and ha35 transcripts are about twofold higher than those of $h a 17$ and $h a 70$. In contrast, in non sporulated culture of Hall strain, the relative levels of expression of bont/A and antps are similar, whereas, in sporulated cultures each ha gene is expressed twofold higher than bont/A and ntnh/A (Couesnon et al., 2006).

In $C$. botulinum E, where no botR gene was found up to now, the kinetics of BoNT/E production and the relative expression of bont/E and $p 47$ are the same as in C. botulinum $\mathrm{A}$. 
bont/E and p47 are also expressed during the transition phase (Couesnon et al., 2006). All of these results support the fact that BotR is an alternative sigma factor specific to the transition phase, like TcdR in C. difficile (Dupuy and Sonenshein, 1998; Hundsberger et al., 1997; Mani et al., 2002) and other alternative sigma factors. The time correlation between the expression of BotR and the other botulinum locus genes suggests that BotR is a key regulatory factor.

\subsection{Two-component systems are involved in the regulation of BoNT synthesis}

Two-component systems (TCSs) consist in a sensor histidine kinase (SHK), which detects a signal and autophosphorylates on a histidyl residue. The phosphate group is then transferred to a conserved aspartyl residue of the response regulator (RR) protein which is typically a DNA-binding protein that regulates target gene expression (Federle and Bassler, 2003). Some TCSs are known to be involved in the regulation of virulence factors in Gramnegative and Gram-positive bacteria. Sequencing of $C$. botulinum genomes has identified numerous potential regulatory systems, including TCSs. According to Sebaihai et al. $C$. botulinum strain Hall genome contains 28 putative TCSs, 8 orphan histidine kinases, 8 orphan response regulators, and 15 sigma factors (Sebaihia et al., 2007). Further analyses show that 39 proteins could be considered as RRs: they all possessed the signal receiver domain Rec (cd09944) and an additional domain, usually the DNA binding domain HTH_XRE (c100088) or LytTR (c104498) (Connan et al., 2012). This is in agreement with the recent analysis of Galperin et al. (Galperin et al., 2010) showing that bacterial signal transduction proteins retain a conserved protein family profile. Indeed, of the 39 RRs that we have identified in the Hall strain genome, the majority (26) belongs to the OmpR family (COG0745) consisting of RRs with a CheY-like receiver domain and a winged-helix DNA-binding domain, and 4 other RRs were LytR family members (COG3279). Nine RRs were orphan regulators and 30 RR genes were located next to a gene coding for a SHK, as judged by the presence of two domains in the respective gene product, a histidine kinase-like ATPase (HATPase_c, cd00075) and a histidine kinase A (dimerization/phosphoacceptor) domain (HisKA, cl00080). Most TCSs of C. botulinum strain Hall have close homologues in other Clostridia. Besides C. sporogenes, which is phenotypically related to $C$. botulinum but non-toxigenic, homologs TCSs exist in particular in C. carboxidivorans. However, 12 RRs have low similarity to proteins in other clostridia. Two RRs (CLC_0632 and CLC_1105) show homology (38 and 37\% protein identity, respectively) to the VirR regulator, which is part of the Clostridium perfringens TCS VirR-VirS involved in the regulation of numerous toxins in this bacterium (Ba-Thein et al., 
1996; Cheung et al., 2009; Cheung et al., 2010; Hassan et al., 2010; Ma et al., 2011; Ohtani et al., 2009; Ohtani et al., 2003; Okumura et al., 2008).

A total of 34 Hall isogenic antisense strains have been generated with the antisense mRNA method targeting 29 regulatory genes predicted to be part of TCSs and 5 putative orphan RR genes to investigate their potential participation in the control of toxin synthesis. Among the 34 Hall isogenic antisense strains, 31 retained similar growth kinetics compared to the control strain, whereas 2 strains showed a more rapid growth and one isogenic antisense strain had a significantly delayed growth. In this last strain, BoNT/A production was delayed but reached the same level compared to the wild type strain. This indicates that the corresponding orphan RR (CLC_0632) is involved in global metabolism but does not directly control toxin synthesis (Connan et al., 2012). Despite their relatedness, the two regulatory genes, CLC_0632 and VirR, are involved in distinct regulation pathways in C. botulinum and C. perfringens, general metabolism and toxinogenseis, respectively. Another TCS (CBO0366/CBO0365) has been found to be involved in the adaptation of growth of $C$. botulinum type A to low temperature. Indeed, this TCS is expressed when bacteria are incubated at $15^{\circ} \mathrm{C}$ and only at a low level at $37^{\circ} \mathrm{C}$. Its role in toxin synthesis has not been reported (Lindstrom et al., 2012).

Three TCSs, CLC_1093/CLC_1094, CLC_1914/CLC_1913 and CLC_0661/CLC_0663 have been found to be involved in the regulation of BoNT/A and ANTP production. BoNT/A and ANTPs were repressed in the corresponding antisense isogenic strains similarly to that observed in the $\operatorname{bot} R / A$ isogenic antisense strain. However, $\operatorname{bot} R / A$ expression was not affected or even slightly increased in the three Hall isogenic antisense strains. These results argue that these three TCSs, control, directly or indirectly, the expression of the botulinum locus genes independently of botR/A (Connan et al., 2012). Thereby, BoNT/A and ANTPs are under the control of a complex regulatory network involving an alternative sigma factor and at least three TCSs which are positive regulators. The regulatory pathways encompassing these three TCSs and toxin regulation in other $C$. botulinum types remains to be identified.

In addition, another TCS (CBO0787/CBO0786) has recently been reported to negatively regulate the production of BoNT/A and ANTP in C. botulinum A. The regulator of this TCS binds to the promoter of the two operons, ntnh-bont/A and $h a$, and prevents BotR/A interaction with these same promoters, thus impairing the transcription of bont and antp genes (Lindstrom, 2012). 


\subsection{Quorum sensing}

Quorum sensing allows bacteria to sense cell population density and to coordinate their reponse to a change in cell number. This mechanism plays an important role in bacterial interactions and in the control of virulence factor synthesis by many pathogenic bacteria. This mechanism was first discovered in the 70's in two bioluminescent bacteria first called Photobacterium fischeri and Photobacterium harveyi and then renamed Vibrio fischeri and Vibrio harveyi, respectively. Bacteria sense their cell density by measuring the concentration of small molecules called autoinducers (AIs) first synthesized as precursor then cleaved and exported in the environment through an $\mathrm{ABC}$ transport system. The detection is performed by a TCS, which regulates specific genes. Two models have been described: one permitting the communication within species (Vibrio fischeri model) and another one for inter-species communication (Vibrio harveyi model) (Eberhard, 1972; Federle and Bassler, 2003; Waters and Bassler, 2005).

AI-2 is a furanosyl borate diester synthetised by LuxS from SAM (Sadenosylmethionine). Numerous bacteria contains $\operatorname{luxS}$ in their genome and thus AI-2 can be detected by different species allowing the interspecies communication (reviewed in (Waters and Bassler, 2005). The role of LuxS in toxinogenesis has been evidenced in Clostridium perfringens. The TCS VirR/VirS has a pleiotropic effect and regulates not only toxin genes but also an operon containing $\operatorname{luxS}$. LuxS acts in the mid exponential growth phase and upregulates the production of alpha toxin, perfringolysin and kappa protease (Ohtani et al., 2002). In Clostridium difficile, AI-2 seems to positively regulate the transcription of Toxin A and Toxin B genes as well as that of $t c d E$. But the role of quorum sensing in the control of toxinogenesis has not been clearly evidenced in this Clostridium species (Lee and Song, 2005). A $\operatorname{luxS}$ related gene has been found in C. botulinum A strain Hall genome and an isogenic antisense strain targeting $\operatorname{lux} S$ has been generated. Only a short delay in bont/A transcription and toxin production was observed in our growth condition compared to the wild type strain (unpublished). The role of this $\operatorname{luxS}$ gene in $C$. botulinum remains to be determined.

Intra-species communication has been described in Gram-positive bacteria, in which the autoinducers are peptides (AIP) recognized by specific TCSs (Waters and Bassler, 2005). A quorum sensing system related to that of Staphylococcus aureus and consisting of two agr loci has been identified in the group I of $C$. botulinum strains, which controls both sporulation and BoNT production. Each agr locus seems to have a specific function, agr-1 regulating sporulation and agr-2 regulating BoNT synthesis (Cooksley et al., 2010). We have also 
identified homologous genes to $\operatorname{agr} A$ and $\operatorname{agrC}$ from $S$. aureus in the Hall genome. The isogenic antisense strain Hall/651 targeting the agrA homolog was not impaired in BoNT production (Connan et al., 2012). Thus, the quorum sensing-dependent regulation pathway and its effects on the control of toxin production in C. botulinum remain to be defined.

\subsection{Small regulatory $R N A$}

Ten to $20 \%$ of bacterial genome DNA, most often located in intergenic regions, encode regulatory RNAs. Small regulatory RNAs (sRNAs) were first discovered in the 70's. Usually, sRNAs are 10 to 500 nucleotides long, but can reach 1000 nucleotides or cover a whole gene, and are considered as stable molecules (20 to 60 min half live times) (Argaman et al., 2001). sRNAs are major transcriptional or posttranscriptional regulators of the adaptive response and thus are also called sensor RNAs. Some of them act in cis by changing their own conformational structure in response to physical factors such as temperature (for example in Yersinia pestis, Escherichia coli or Listeria monocytogenes), or by binding to a metabolite (riboswitch) (Klinkert and Narberhaus, 2009; Narberhaus et al., 2006). In addition, cisencoded sRNAs, which are transcribed from the non-coding DNA strand, exhibit perfect sequence complementary with the target mRNA permitting a regulation by an antisense base paired mechanism (Waters and Bassler, 2005). However, most sRNAs are active in trans. A few acts by a protein sequestration mechanism, like the system CsrA/CsrB (Gutierrez et al., 2005), but most of them use a base pairing mechanism with mRNAs, thus regulating the translation and/or stability of target mRNAs. They act at distance from their production site and thus exhibit a low complementarity with their targets. Thereby, one sRNA might target different mRNAs and one mRNA can be regulated by different sRNAs. Considering the low sequence complementarity between sRNAs and mRNA targets, many sRNAs require a chaperone protein, called Hfq, to interact with their targets (reviewed in (Thomason and Storz, 2010). It is noteworthy that a sRNA can act in cis or trans, or both. and some of them can be transcribed in protein. Recently, a new type of sRNAs has been described, termed clustered regulatory interspaced short palindromic (CRISPR) repeats, which interfere with bacteriophage infection and plasmid conjugation (Sorek et al., 2008).

Numerous sRNAs are involved in the regulation of virulence factor synthesis in bacteria (Toledo-Arana et al., 2007) and also participate to the quorum sensing mechanism, like RNA III, which plays a significant role in Agr quorum sensing system in Staphylococcus aureus (Novick and Geisinger, 2008). In C.perfringens, a sRNA, called VR-RNA, controls at the transcriptional level the synthesis of collagenase A and alpha toxin (Shimizu et al., 2002). 
A large number of potential sRNAs has been identified in the genomes of 21 Clostridium species including C. botulinum (231 to 249), C. difficile (264), C. perfringens (131 to 193) and $C$. tetani (137) by a computational approach. Most of these sRNAs are unique to the Clostridium genus and are not found in bacterial from other phylum. Interestingly, pathogenic Clostridia seem to share common sRNAs, which could reflect common regulatory mechanism of virulence factor production or adaptation to an ecological niche (Chen et al., 2011). The role of sRNAs in the control of neurotoxin production remains to be defined.

\subsection{Environmental signals}

It is not known whether BotR and TetR are the only regulatory genes or are involved in a regulation cascade and which are the environmental signals that trigger the production of the neurotoxins and ANTPs. In C. difficile, a catabolic repression of the expression of Toxin A and Toxin B genes by rapidly metabolizable sugars such as glucose has been evidenced (Dupuy and Sonenshein, 1998). No such regulation has been identified in C. botulinum and $C$. tetani. Carbon source, amino-acids, biotin, and growth temperature have been found to regulate the production of Toxin A and B in C. difficile (Dupuy and Sonenshein, 1998; Karlsson et al., 1999; Karlsson et al., 2003; Yamakawa et al., 1998). In contrast to C. difficile, C. botulinum requires glucose for high toxin production. $\mathrm{CO} 2$ seems to stimulate the bont/B expression and subsequent BoNT/B production (Lövenklev et al., 2004). Indeed, carbon dioxide has been reported to stimulate toxin gene expression and toxin formation in nonproteolytic C. botulinum strains type B and E despite a growth rate reduction (Artin et al., 2008; Lövenklev et al., 2004), in contrast to proteolytic C. botulinum type A which seems insensitive to carbon dioxide (Artin et al., 2010). Availability of certain nutrients, in particular the nitrogen and carbon sources, is important for toxinogenesis in C. botulinum and C. tetani. A high level of arginine in minimal medium represses BoNT/A and protease production, whereas casein complementation increases both toxin and protease synthesis (Patterson-Curtis and Johnson, 1989). Moreover, specific short peptides from media containing pancreatic digest of casein are essential for toxin production in C. tetani (Porfirio et al., 1997).

Temperature is a common signal involved in the control of alternative sigma factors and subsequent regulated genes expression. In C. difficile, a temperature of $42^{\circ} \mathrm{C}$ prevents transcription of $t c d R$ and subsequent expression of $t c d A$ and $t c d B$ (Karlsson et al., 2003). In $C$. botulinum, high temperature is not an inhibitory signal for toxin gene regulation (Couesnon et al., 2006). Indeed, expression of botR/A and other botulinum locus genes was not temperature sensitive, within $37-44^{\circ} \mathrm{C}$ range. But BoNT/A lethal activity decreases in cultures incubated at 
$44^{\circ} \mathrm{C}$ for $24-48 \mathrm{~h}$. Analysis of temperature-dependent stability of BoNT/A and ANTPs showed that NTNH/A and BoNT/A are sensitive to a proteolysis at $44^{\circ} \mathrm{C}$, in contrast to HAs proteins. $\mathrm{A} \mathrm{Ca}^{++}$-dependent protease produced by $C$. botulinum $\mathrm{A}$ is probably activated at $44^{\circ} \mathrm{C}$ leading to BoNT/A and NTNH/A degradation, whereas at $37^{\circ} \mathrm{C}$ this protease only promotes the proteolytic activation of BoNT/A (Couesnon et al., 2006). In contrast, C. botulinum E produces no protease activated at $44^{\circ} \mathrm{C}$, and $\mathrm{BoNT} / \mathrm{E}$ as well as $\mathrm{NTNH} / \mathrm{E}$ are stable in culture supernatant incubated at $44^{\circ} \mathrm{C}$ (Couesnon et al., 2006).

\section{5 . CONCLUDING REMARKS}

Homologies at the amino acid and protein structure levels between BoNTs and TeNT suggest that their genes have evolved from a common ancestor. Neurotoxin gene localization on mobile structures and/or mobile DNA elements accounts for gene transfer between strains from intra and inter Clostridium species. It is noteworthy that TeNT is unique and is produced by a homogeneous Clostridium species, whereas bont genes show a high degree of variability and are harbored by various Clostridium species and strains.

The production of the clostridial neurotoxins is a regulated process, in which BotR and TetR are required. BotR and TetR are alternative RNA polymerase sigma factors from group 5 of the $\sigma^{70}$ family, containing also TcdR and UviA from C. difficile and C. perfringens, respectively. Therefore, $C$. botulinum and $C$. tetani probably share a common mechanism of toxin gene expression, which is probably related to that of toxin and bacteriocin synthesis in C. difficile and $C$. perfringens, respectively. Additional regulatory factors such as twocomponent systems in response to unknown signal, and/or environmental or nutritional factors are also possibly involved in the toxinogenesis. Unraveling the mechanism of toxin regulation is essential to optimize the neurotoxin production for vaccine preparation or for therapeutic use, and to develop new strategies to control botulism and tetanus. 


\section{REFERENCES}

Argaman, L., Hershberg, R., Vogel, J., Bejerano, G., Wagner, E.G., Margalit, H., Altuvia, S., 2001. Novel small RNA-encoding genes in the intergenic regions of Escherichia coli. Curr Biol 11, 941-950.

Artin, I., Carter, A.T., Holst, E., Lovenklev, M., Mason, D.R., Peck, M.W., Radstrom, P., 2008. Effects of carbon dioxide on neurotoxin gene expression in nonproteolytic Clostridium botulinum Type E. Appl Environ Microbiol 74, 2391-2397.

Artin, I., Mason, D.R., Pin, C., Schelin, J., Peck, M.W., Holst, E., Radstrom, P., Carter, A.T., 2010. Effects of carbon dioxide on growth of proteolytic Clostridium botulinum, its ability to produce neurotoxin, and its transcriptome. Appl Environ Microbiol 76, 11681172.

Ba-Thein, W., Lyristis, M., Ohtani, K., Nisbet, I.T., Hayashi, H., 1996. The virR/virS locus regulates the transcription of genes encoding extracellular toxin production in Clostridium perfringens. J. Bacteriol. 178, 2514-2520.

Bhandari, M., Campbell, K.D., Collins, M.D., East, A.K., 1997. Molecular characterization of the clusters of genes encoding the botulinum neurotoxin complex in Clostridium botulinum (Clostridium argentinense) type $\mathrm{G}$ and nonproteolytic Clostridium botulinum type B. Curr. Microbiol. 35, 207-214.

Bradshaw, M., Dineen, S.S., Maks, N.D., Johnson, E.A., 2004. Regulation of neurotoxin complex expression in Clostridium botulinum strains 62A, Hall A-hyper, and NCTC2916. Anaerobe 10, 321-333.

Brüggemann, H., Bäumer, S., Fricke, W.F., Wiezr, A., Liesagang, H., Decker, I., Herzberg, C., Martinez-Arias, R., Henne, A., Gottschalk, G., 2003. The genome sequence of Clostridium tetani, the causative agent of tetanus disease. Proc. Ntl. Acad. Sci. (USA) 100, 1316-1321.

Carter, A.T., Paul, C.J., Mason, D.R., Twine, S.M., Alston, M.J., Logan, S.M., Austin, J.W., Peck, M.W., 2009. Independent evolution of neurotoxin and flagellar genetic loci in proteolytic Clostridium botulinum. BMC Genomics 10, 115.

Chen, Y., Indurthi, D.C., Jones, S.W., Papoutsakis, E.T., 2011. Small RNAs in the genus Clostridium. MBio 2, e00340-00310.

Chen, Y., Korkeala, H., Aarnikunnas, J., Lindstrom, M., 2007. Sequencing the botulinum neurotoxin gene and related genes in Clostridium botulinum type E strains reveals orfx3 and a novel type E neurotoxin subtype. J Bacteriol 189, 8643-8650. 
Cheung, J.K., Awad, M.M., McGowan, S., Rood, J.I., 2009. Functional analysis of the VirSR phosphorelay from Clostridium perfringens. PLoS One 4, e5849.

Cheung, J.K., Keyburn, A.L., Carter, G.P., Lanckriet, A.L., Van Immerseel, F., Moore, R.J., Rood, J.I., 2010. The VirSR two-component signal transduction system regulates NetB toxin production in Clostridium perfringens. Infect Immun 78, 3064-3072.

Connan, C., Brueggemann, H., Mazuet, C., Raffestin, S., Cayet, N., Popoff, M.R., 2012. TwoComponent Systems Are Involved in the Regulation of Botulinum Neurotoxin Synthesis in Clostridium botulinum Type A Strain Hall. PLoS One 7.

Cooksley, C.M., Davis, I.J., Winzer, K., Chan, W.C., Peck, M.W., Minton, N.P., 2010. Regulation of neurotoxin production and sporulation by a Putative agrBD signaling system in proteolytic Clostridium botulinum. Appl Environ Microbiol 76, 4448-4460.

Couesnon, A., Raffestin, S., Popoff, M.R., 2006. Expression of botulinum neurotoxins A and E, and associated non-toxin genes, during the transition phase and stability at high temperature : analysis by quantitative reverse transcription-PCR. Microbiol. 152, 759770.

Dineen, S.S., Bradshaw, M., Karasek, C.E., Johnson, E.A., 2004. Nucleotide sequence and transcriptional analysis of the type A2 neurotoxin gene cluster in Clostridium botulinum. FEMS Microbiol. Lett. 235, 9-16.

Dupuy, B., Mani, N., Katayama, S., Sonenshein, A.L., 2005. Transcription activation of a UV-inducible Clostridium perfringens bacteriocin gene by a novel sigma factor. Mol Microbiol 55, 1196-1206.

Dupuy, B., Raffestin, S., Matamouros, S., Mani, N., Popoff, M.R., Sonenshein, A.L., 2006. Regulation of toxin and bacteriocin gene expression in Clostridium by interchangeable RNA polymerase sigma factors. Mol. MIcrobiol. 60, 1044-1057.

Dupuy, B., Sonenshein, A.L., 1998. Regulated transcription of Clostridium difficile toxin genes. Mol. Microbiol. 27, 107-120.

East, A.K., Bhandari, M., Stacey, J.M., Campbell, K.D., Collins, M.D., 1996. Organization and phylogenetic interrelationships of genes encoding components of the botulinum toxin complex in proteolytic Clostridium botulinum types A, B, and F: evidence of chimeric sequences in the gene encoding the nontoxic nonhemagglutinin component. Int. J. Syst. Bacteriol. 46, 1105-1112.

Eberhard, A., 1972. Inhibition and activation of bacterial luciferase synthesis. J Bacteriol 109, 1101-1105. 
Eklund, M.W., Poysky, F.T., Habig, W.H., 1989. Bacteriophages and plasmids in Clostridium botulinum and Clostridium tetani and their relationship to production of toxins., in: Simpson, L.L. (Ed.), Botulinum Neurotoxin and Tetanus Toxin. Academic Press, San Diego, pp. 25-51.

Federle, M.J., Bassler, B.L., 2003. Interspecies communication in bacteria. J Clin Invest 112, 1291-1299.

Franciosa, G., Ferreira, J.L., Hatheway, C.L., 1994. Detection of type A, B, and E botulism neurotoxin genes in Clostridium botulinum and other Clostridium species by PCR: evidence of unexpressed type B toxin genes in type A toxigenic organisms. J. Clin. Microbiol. 32, 1911-1917.

Franciosa, G., Maugliani, A., Scalfaro, C., Aureli, P., 2009. Evidence that plasmid-borne botulinum neurotoxin type B genes are widespread among Clostridium botulinum serotype B strains. PLoS One 4, e4829.

Galperin, M.Y., Higdon, R., Kolker, E., 2010. Interplay of heritage and habitat in the distribution of bacterial signal transduction systems. Mol Biosyst 6, 721-728.

Gutierrez, P., Li, Y., Osborne, M.J., Pomerantseva, E., Liu, Q., Gehring, K., 2005. Solution structure of the carbon storage regulator protein CsrA from Escherichia coli. J Bacteriol 187, 3496-3501.

Hall, J.D., McCroskey, L.M., Pincomb, B.J., Hatheway, C.L., 1985. Isolation of an organism resembling Clostridium barati which produces type F botulinal toxin from an infant with botulism. J. Clin. Microbiol. 21, 654-655.

Hassan, S., Ohtani, K., Wang, R., Yuan, Y., Wang, Y., Yamaguchi, Y., Shimizu, T., 2010. Transcriptional regulation of hemO encoding heme oxygenase in Clostridium perfringens. J Microbiol 48, 96-101.

Hauser, D., Gibert, M., Marvaud, J.C., Eklund, M.W., Popoff, M.R., 1995. Botulinal neurotoxin $\mathrm{C} 1$ complex, Clostridial neurotoxin homology and genetic transfer in Clostridium botulinum. Toxicon 33, 515-526.

Helmann, J.D., 2002. The extracytoplasmic function (ECF) sigma factors. Adv. Microbial. Physiol. 46, 47-110.

Henderson, I., Davis, T., Elmore, M., Minton, N., 1997. The genetic basis of toxin production in Clostridium botulinum and Clostridium tetani, in: Rood, I. (Ed.), The Clostridia: Molecular Biology and Pathogenesis. Academic Press, New York, pp. 261-294. 
Henderson, I., Whelan, S.M., Davis, T.O., Minton, N.P., 1996. Genetic characterization of the botulinum toxin complex of Clostridium botulinum strain NCTC2916. FEMS Microbiol. Lett. 140, 151-158.

Hill, K.K., Smith, T.J., Helma, C.H., Ticknor, L.O., Foley, B.T., Svensson, R.T., Brown, J.L., Johnson, E.A., Smith, L.A., Okinaka, R.T., Jackson, P.J., Marks, J.D., 2007. Genetic diversity among Botulinum Neurotoxin-producing clostridial strains. J Bacteriol 189, 818-832.

Hill, K.K., Xie, G., Foley, B.T., Smith, T.J., Munk, A.C., Bruce, D., Smith, L.A., Brettin, T.S., Detter, J.C., 2009. Recombination and insertion events involving the botulinum neurotoxin complex genes in Clostridium botulinum types A, B, E and F and Clostridium butyricum type E strains. BMC Biol 7, 66.

Hirst, T.R., 1995. Biogenesis of cholera toxin and related oligomeric toxins, in: Moss, J., Iglewsski, B., Vaughan, M., Tu, A.T. (Eds.), Bacterial Toxins and Virulence Factors in Disease. Marcel Dekker, New York, pp. 123-184.

Hundsberger, T., Braun, V., Weidmann, M., Leukel, P., Sauerborn, M., von Eichel-Streiber, C., 1997. Transcription analysis of the genes $t c d A-E$ of the pathogenicity locus of Clostridium difficile. Eur. J. Biochem. 244, 735-742.

Hutson, R.A., Zhou, Y., Collins, M.D., Johnson, E.A., Hatheway, C.L., Sugiyama, H., 1996. Genetic characterization of Clostridium botulinum type A containing silent type B neurotoxin gene sequences. J. Biol. Chem. 271, 10786-10792.

Inoue, K., Fujinaga, Y., Watanabe, T., Ohyama, T., Takeshi, K., Moriishi, K., Nakajima, H., Inoue, K., Oguma, K., 1996. Molecular composition of Clostridium botulinum type A progenitor toxins. Infect. Immun. 64, 1589-1594.

Jacobson, M.J., Lin, G., Raphael, B., Andreadis, J., Johnson, E.A., 2008. Analysis of neurotoxin cluster genes in Clostridium botulinum strains producing botulinum neurotoxin serotype A subtypes. Appl Environ Microbiol 74, 2778-2786.

Jovita, M.R., Collins, M.D., East, A.K., 1998. Gene organization and sequence determination of the two botulinum neurotoxin gene clusters in Clostridium botulinum. Cur. Microbiol. $36,226-231$.

Karlsson, S., Burman, L.G., Akerlund, T., 1999. Suppression of toxin production in Clostridium difficile VPI10463 by amino acids. Microbiol. 145, 1683-1693.

Karlsson, S., Dupuy, B., Mukherjee, K., Norin, E., Burman, L.G., Akerlund, T., 2003. Expression of Clostridium difficile toxins A and B and their sigma factor TcdD is controlled by temperature. Infect. Immun. 71, 1784-1793. 
Klinkert, B., Narberhaus, F., 2009. Microbial thermosensors. Cell Mol Life Sci 66, 26612676.

Lee, A.S., Song, K.P., 2005. LuxS/autoinducer-2 quorum sensing molecule regulates transcriptional virulence gene expression in Clostridium difficile. Biochem Biophys Res Commun 335, 659-666.

Li, B., Qian, X., Sarkar, H.K., Singh, B.R., 1998. Molecular characterization of type E Clostridium botulinum and comparison to other types of Clostridium botulinum. Biochim. Biophys. Acta 1395, 21-27.

Lin, W.J., Johnson, E.A., 1995. Genome analysis of Clostridium botulinum type A by pulsedfield gel electrophoresis. Appl. Environ. Microbiol. 61, 4441-4447.

Lindstrom, M., 2012. Identification of a two-component signal transduction system repressing neurotoxin production in group I Clostridium botulinum type A strain ATCC3502, Toxins2012, Miami.

Lindstrom, M., Dahlsten, E., Soderholm, H., Selby, K., Somervuo, P., Heap, J.T., Minton, N.P., Korkeala, H., 2012. Involvement of Two-Component System CBO0366/CBO0365 in the Cold Shock Response and Growth of Group I (Proteolytic) Clostridium botulinum ATCC 3502 at Low Temperatures. Appl Environ Microbiol 78, 5466-5470.

Lövenklev, M., Artin, I., Hagberg, O., Borch, E., Holst, E., Radström, P., 2004. Quantitative interaction effects of carbon dioxide, sodium chloride, and sodium nitrite on neurotoxin gene expression in nonproteolytic Clostridium botulinum type B. Appl. Environ. Micrcobiol. 70, 2928-2934.

Ma, M., Vidal, J., Saputo, J., McClane, B.A., Uzal, F., 2011. The VirS/VirR two-component system regulates the anaerobic cytotoxicity, intestinal pathogenicity, and enterotoxemic lethality of Clostridium perfringens type C isolate CN3685. MBio 2, e00338-00310.

Mani, N., Lyras, D., Barroso, L., Howarth, P., Wilkins, T., Rood, J.I., Sonenshein, A.L., Dupuy, B., 2002. Environmental response and autoregulation of Clostridiium difficile TxeR, a sigma factor for toxin gene expression. J. Bacteriol. 184, 5971-5978.

Marshall, K.M., Bradshaw, M., Pellet, S., Johnson, E.A., 2007. Plasmid encoded neurotoxin genes in Clostridium botulinum serotype A subtypes. Biochem Biophys Res Commun $361,49-54$.

Marvaud, J.C., Eisel, U., Binz, T., Niemann, H., Popoff, M.R., 1998a. tetR is a positive regulator of the Tetanus toxin gene in Clostridium tetani and is homologous to botR. Infect. Immun. 66, 5698-5702. 
Marvaud, J.C., Gibert, M., Inoue, K., Fujinaga, V., Oguma, K., Popoff, M.R., 1998b. botR is a positive regulator of botulinum neurotoxin and associated non toxic protein genes in Clostridium botulinum A. Mol. Microbiol. 29, 1009-1018.

McCroskey, L.M., Hatheway, C.L., Fenicia, L., Pasolini, B., Aureli, P., 1986.

Characterization of an organism that produces type E botulinal toxin but which resembles Clostridium butyricum from the feces of an infant with type E botulism. J. Clin.

Microbiol. 23, 201-202.

McCroskey, L.M., Hatheway, C.L., Woodruff, B.A., Greenberg, J.A., Jurgenson, P., 1991. Type F botulism due to neurotoxigenic Clostridium baratii from an unknown source in an adult. J. Clin. Microbiol. 29, 2618-2620.

Nakamura, S., Okado, I., Abe, T., Nishida, S., 1979. Taxonomy of Clostridium tetani and related species. J. Gen. Microbiol. 113, 29-35.

Narberhaus, F., Waldminghaus, T., Chowdhury, S., 2006. RNA thermometers. FEMS Microbiol Rev 30, 3-16.

Novick, R.P., Geisinger, E., 2008. Quorum sensing in staphylococci. Annu Rev Genet 42, 541-564.

Ohtani, K., Hayashi, H., Shimizu, T., 2002. The $\operatorname{luxS}$ gene is involved in cell-cell signalling for toxin production in Clostridium perfringens. Mol. Microbiol. 44, 171-179.

Ohtani, K., Hirakawa, H., Tashiro, K., Yoshizawa, S., Kuhara, S., Shimizu, T., 2009. Identification of a two-component VirR/VirS regulon in Clostridium perfringens. Anaerobe 16, 258-264.

Ohtani, K., Kawsar, H.I., Okumura, K., Hayashi, H., Shimizu, T., 2003. The VirR/VirS regulatory cascade affects transcription of plasmid-encoded putative virulence genes in Clostridium perfringens strain 13. FEMS Microbiol. Lett. 222, 137-141.

Okumura, K., Ohtani, K., Hayashi, H., Shimizu, T., 2008. Characterization of genes regulated directly by the VirR/VirS system in Clostridium perfringens. J Bacteriol 190, 7719-7727.

Patterson-Curtis, S.I., Johnson, E.A., 1989. Regulation of neurotoxin and protease formation in Clostridium botulinum Okra B and Hall by arginine. Appl. Environ. Microbiol. 55, 1544-1548.

Popoff, M.R., Marvaud, J.C., 1999. Structural and genomic features of clostridial neurotoxins, in: Alouf, J.E., Freer, J.H. (Eds.), The Comprehensive Sourcebook of Bacterial Protein Toxins, 2 ed. Academic Press, London, pp. 174-201. 
Porfirio, Z., Prado, S.M., Vancetto, M.D.C., Fratelli, F., Alves, E.W., Raw, I., Fernandes, B.L., Camargo, A.C.M., Lebrun, I., 1997. Specific peptides of casein pancreatic digestion enhance the production of tetanus toxin. J. Appl. Microbiol. 83, 678-684.

Poulain, B., Stiles, B.G., Popoff, M.R., Molgó, J., 2006. Attack of the nervous system by clostridial toxins: Physical findings, cellular and molecular actions, in: Alouf, J.E., Popoff, M.R. (Eds.), The Sourcebook of Bacterial Protein Toxins, $3^{\circ}$ ed. Elsevier, Academic Press, Amsterdam, pp. 348-389.

Raffestin, S., Dupuy, B., Marvaud, J.C., Popoff, M.R., 2005. BotR/A and TetR are alternative RNA polymerase sigma factors controlling the expression of the neurotoxin and associated protein genes in Clostridium botulinum type A and Clostridium tetani. Mol. MIcrobiol. 55, 235-249.

Raphael, B.H., Lautenschlager, M., Kalb, S.R., de Jong, L.I., Frace, M., Luquez, C., Barr, J.R., Fernandez, R.A., Maslanka, S.E., 2012. Analysis of a unique Clostridium botulinum strain from the Southern hemisphere producing a novel type E botulinum neurotoxin subtype. BMC Microbiol 12, 245.

Sebaihia, M., Peck, M.W., Minton, N.P., Thomson, N.R., Holden, M.T., Mitchell, W.J., Carter, A.T., Bentley, S.D., Mason, D.R., Crossman, L., Paul, C.J., Ivens, A., WellsBennik, M.H., Davis, I.J., Cerdeno-Tarraga, A.M., Churcher, C., Quail, M.A., Chillingworth, T., Feltwell, T., Fraser, A., Goodhead, I., Hance, Z., Jagels, K., Larke, N., Maddison, M., Moule, S., Mungall, K., Norbertczak, H., Rabbinowitsch, E., Sanders, M., Simmonds, M., White, B., Whithead, S., Parkhill, J., 2007. Genome sequence of a proteolytic (Group I) Clostridium botulinum strain Hall A and comparative analysis of the clostridial genomes. Genome Res 17, 1082-1092.

Shimizu, T., Yaguchi, H., Ohtani, K., Banu, S., Hayashi, H., 2002. Clostridial VirR/VirS regulon involves a regulatory RNA molecule for expression of toxins. Mol. Microbiol. 43, 257-265.

Skarin, H., Segerman, B., 2011. Horizontal gene transfer of toxin genes in Clostridium botulinum: Involvement of mobile elements and plasmids. Mob Genet Elements 1, 213 215.

Smith, L.D.S., 1975. Clostridium tetani, in: Smith, L.D.S. (Ed.), The Pathogenic Anaerobic Bacteria. Charles C. Thomas Publisher, Springfield Ill, pp. 177-201.

Smith, T.J., Hill, K.K., Foley, B.T., Detter, J.C., Munk, A.C., Bruce, D.C., Doggett, N.A., Smith, L.A., Marks, J.D., Xie, G., Brettin, T.S., 2007. Analysis of the Neurotoxin 
Complex Genes in Clostridium botulinum A1-A4 and B1 Strains: BoNT/A3, /Ba4 and /B1 Clusters Are Located within Plasmids. PLoS ONE 2, e1271.

Smith, T.J., Lou, J., Geren, I.N., Forsyth, C.M., Tsai, R., Laporte, S.L., Tepp, W.H., Bradshaw, M., Johnson, E.A., Smith, L.A., Marks, J.D., 2005. Sequence variation within botulinum neurotoxin serotypes impacts antibody binding and neutralization. Infect Immun 73, 5450-5457.

Sorek, R., Kunin, V., Hugenholtz, P., 2008. CRISPR--a widespread system that provides acquired resistance against phages in bacteria and archaea. Nat Rev Microbiol 6, 181 186.

Strom, M.S., Eklund, M.W., Poysky, F.T., 1984. Plasmids in Clostridium botulinum and related species. Appl. Environ. Microbiol. 48, 956-963.

Suen, J.C., Hatheway, C.L., Steigerwalt, A.G., Brenner, D.J., 1988. Clostridium argentinense sp. nov.: a genetically homogeneous group composed of all strains of Clostridium botulinum toxin type $\mathrm{G}$ and some nontoxigenic strains previously identified as Clostridium subterminale or Clostridium hastiforme. Int. J. Syst. Bacteriol. 38, 375-381. Thomason, M.K., Storz, G., 2010. Bacterial antisense RNAs: how many are there, and what are they doing? Annu Rev Genet 44, 167-188.

Toledo-Arana, A., Repoila, F., Cossart, P., 2007. Small noncoding RNAs controlling pathogenesis. Curr Opin Microbiol 10, 182-188.

Waters, C.M., Bassler, B.L., 2005. Quorum sensing: cell-to-cell communication in bacteria. Annu Rev Cell Dev Biol 21, 319-346.

Weickert, M.J., Chambliss, G.H., Sugiyama, H., 1986. Production of toxin by Clostridium botulinum type A strains cured of plasmids. Appl. Environ. Microbiol. 51, 52-56.

Wilde, E., Hippe, H., Tosunoglu, N., Schallehn, G., Herwig, K., Gottschalk, G., 1989. Clostridium tetanomorphum sp. nov., nom rev. Int. J. SysT. Bacteriol. 39, 127-134.

Yamakawa, K., Karasawa, T., Ohta, T., Hayashi, H., Nakamura, S., 1998. Inhibition of enhanced toxin production by Clostridium difficile in biotin-limited conditions. J. Med. Microbiol. 47, 767-771. 